\title{
A Walk through Malegalalli Madumagalu - Lines that Uncover New Ontologies
}

\author{
Deepta Sateesh \\ Doctoral Candidate, Manipal Academy of Higher Education. ORCID: oooo-ooo3-3357-474. \\ Email: odeeptasateesh@gmail.com
}

\begin{abstract}
The Western Ghats is a contentious landscape described in the familiar language of disciplines and boundaries, a language that has influenced the way in which development and environmental projects have been designed. It is possible the contentions arise from a particular ontology, created by a way of seeing the Ghats that divides nature from culture, relying on a view from above that distances one from place, an outsider's view. This way of seeing differs from an understanding that emerges when engaging in the Ghats on foot. This paper grapples with this difference through a literary engagement with one of Kuvempu's epic novels, Malegalalli Madumagalu. The novel reveals two different ontologies through an unraveling of text and imaging: one that privileges the colonial eye requiring skies and eyes to be clear, and another that privileges a local experience structured by the everyday practice of walking in a monsoon terrain.
\end{abstract}

Keywords: Ontology, Western Ghats, Literature, Image \& Text, Visual Literacy.

\section{Experiencing a Monsoon Landscape}

When walking through the monsoon landscape of the Malenadu region, one can see a place that is continually changing; transformations of materials, practices and places. In this landscape, wetness is everywhere, all the time. Bare feet find their way through dew, thorns, puddles, stones, softness of grass, mist. The skin is porous, supple, moist, sensitive in constant humidity. Water seeps into and oozes from the red earth, moss and ferns inhabit places defying surfaces; water finds its way through the depths of tiny cracks and undulations. The ground is alive, in motion, shaping the terrain. Sounds of water engulf the atmosphere, raindrops slow down as they touch leaves, roofs and umbrellas, water gushing finding its way across and into the ground, gurgling, splashing; tireless chirping of mating calls and silences curled up in the warm places above. Smells intoxicate, creating freshness in the atmosphere; the smell of earth when the first rain falls; of fish and squid ink at the fish market; of camphor, cow dung and wet flowers in the temple square; of fast decomposing fruits and vegetables; all soft sensations in the nostrils that are receptive and clear with the moisture in the air. The rain enlivens everything.

This is the experience in the environment of the Ghats, a world of fluidity, temporality and wetness. This experiential description is a very different world from the common descriptions of the Western Ghats in reports, literature and travelogues. This is a world of wetness (Steinberg and Peters, 2015; Cons, 2017).

\section{Looking at the Western Ghats - The Quasi-Scientific Eye}

(c) AesthetixMS 2020. This Open Access article is published under a Creative Commons Attribution Non-Commercial 4.0 International License (http://creativecommons.org/licenses/by-nc/4.0/), which permits non-commercial re-use, distribution, and reproduction in any medium, provided the original work is properly cited. For citation use the DOI. For commercial re-use, please contact editor@rupkatha.com. 
The Western Ghats, also known as the Sahyadris, is a region seen along the west coast of the Indian subcontinent, across six states from its northern tip in Gujarat to Kerala in the south, and is ecologically linked with Sri Lanka. The region as a whole has multiple identities: it is known as one of the world's 'hottest hotspots' of biodiversity (UNESCO, 2012), one of the oldest cloud and rainforests that are home to rare species of frogs and flowers, critical tiger and elephant corridors, ancient practices of agriculture, sacred groves and national parks and the laws that govern them, monsoon catchments, human settlements and the natural resources that support them. The Critical Ecosystem Partnership Fund Report, put together by scientists and research organizations in India, describes the Western Ghats as a region of high cultural diversity and having "important hydrological and watershed functions" (Bawa, et al, 2007). It also discusses the Ghats as having great biological importance and richness, and must therefore be conserved to 'avoid extinctions' (ibid.). Scientific reports suggest the Western Ghats has also been the "backbone of the ecology and economy of south India" (Gadgil, et al, 2011.) This complex and layered place is embedded in a unique geology of basaltic formations, granite beds (from gneiss formations) and laterite structures, all part of the escarpment structure that is still shifting at a geological time scale, forming a threshold between the Arabian Sea and the Deccan Plateau (here, 'threshold' is used as a boundary word). The region has played a critical role in trading resources across the Indian Ocean, with the East India Company exporting cinnamon, cardamom, pepper, and coffee, and iron ore and minerals. A region as rich and complex as the Ghats, continually experiences conflict between extractive activities, and local inhabitants and forest dwellers (Assadi, 2004; Buchanan, 1807; Cleghorn, 1861). This is the inherited picture of the Ghats, a world of objects and spaces viewed from afar, from above, a gaze.

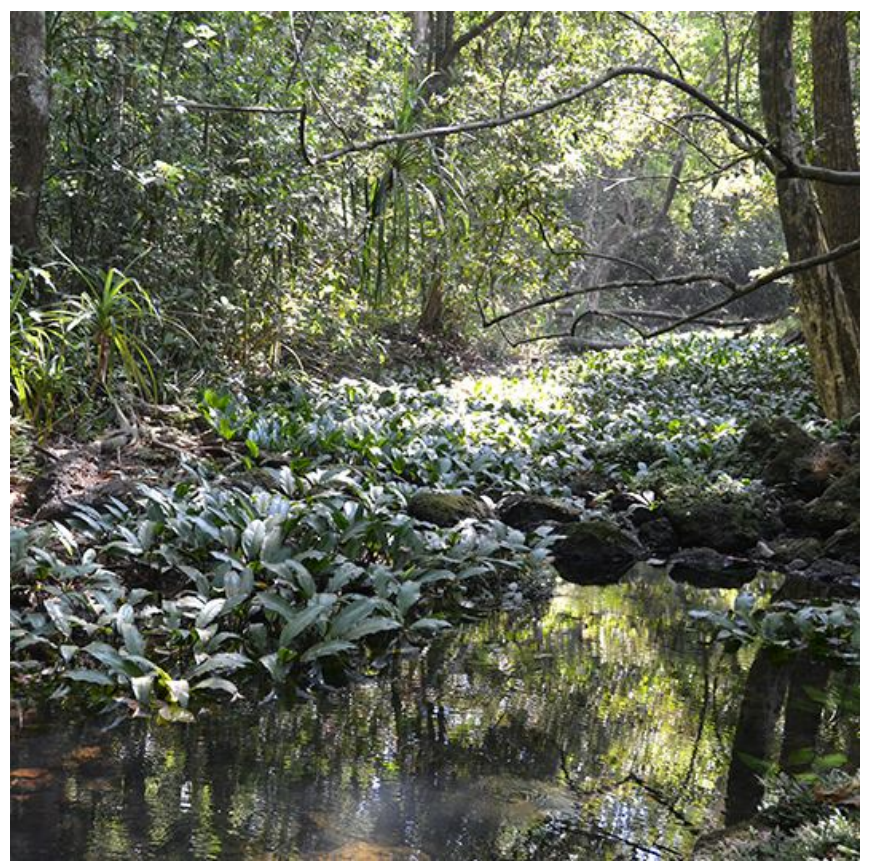

Figure 1: Photograph of the forest in Agumbe, Western Ghats (Photo credit: Deepta Sateesh). 


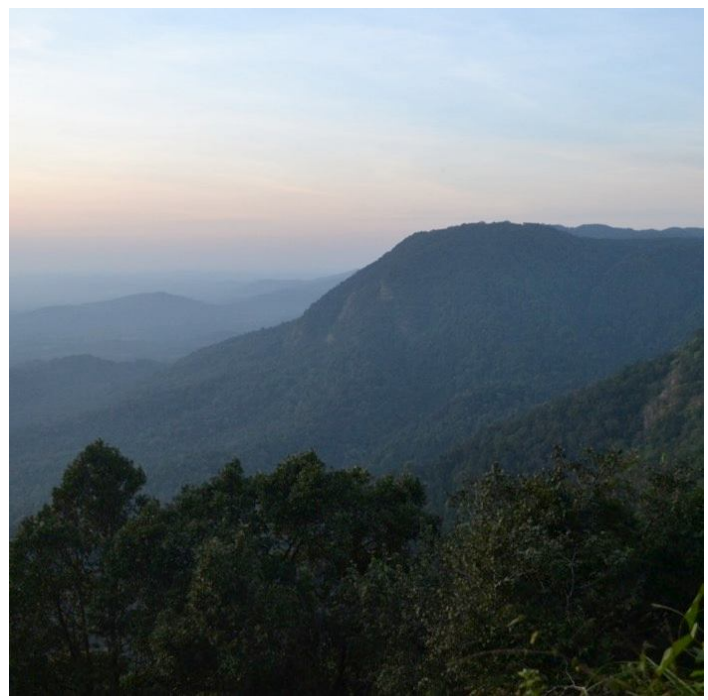

Figure 2: Photograph of the escarpment at Agumbe, Western Ghats (Photo credit: Deepta Sateesh).

This visualization of the universal is characterized by a visual literacy, from reading images, drawings and maps, literature and laws (various forms of representation); as well as a socio-political literacy, constructed by categories of 'things' and their classification systems: species into plants and animals, and their sub-species (amphibians, fish, mammals, birds and reptiles) and so on; similarly, people into castes, religions, gender, language; and places into forests (Figure 1), fields, rivers, cities, escarpment (Figure 2), coast, ridges and valleys (Figure 3 ). Based on visual representations of objects and space, this is the quasi-scientific language, held and perpetuated by academic disciplines. The language of this imaging delinks one from the lived experience of the place, of 'being in the world' (Heidegger, 1996) making one view it from a distance, from above, as the 'other', as an object. This imaging may be seen in many forms of representation - including reports, policies, guide books, text books, local literature, paintings, photographs, texts on biodiversity and conservation, development and progress.

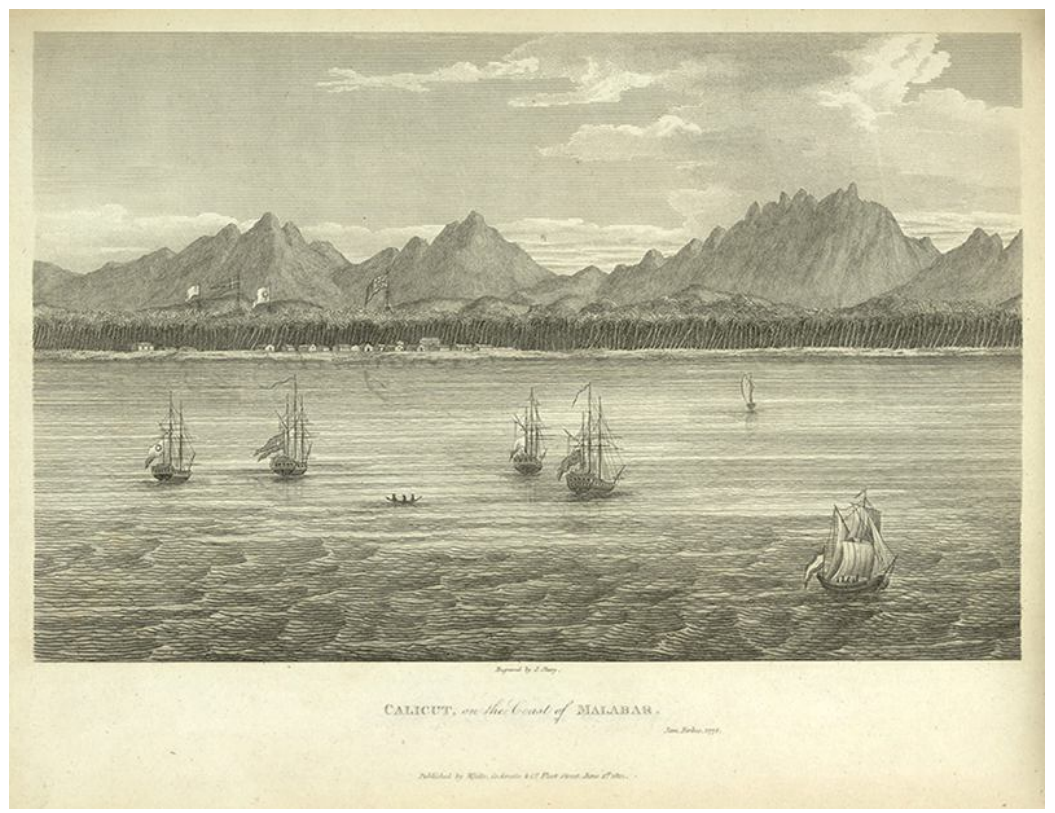

Figure 3: Ridges and valleys. Calicut on the coast of Malabar (Forbes, 1813). 
Since the pre-colonial era, the Western Ghats has been the focus of many kinds of research and activism, related to development and environment, all of which rely on this common imaging of the Ghats. These activities are broadly seen as environmental conservation, social empowerment, economic development and so on, all projects towards improving the status quo, particularly of dwindling resources and an environmental crisis. However, although there have been and continues to be movements to bridge the gap between development and environment, there is little hope. This futility may be attributed to the issue that 'environment' is described in the language of development, emerging from the same way of seeing, or ontology of, the world. It reflects the use of a singular understanding, rather than a multiplicity of possibilities and change.

\section{Ways of Seeing - Approach and Methods}

The relationship between image and text is inextricable. Text paints pictures in the mind, while images bring words to the tongue. However, the image comes prior to text, in the way we see the world. Images are created in the mind when engaging in the world, to make sense of it and relate, to evoke or communicate, to understand and know something; an ontological imaging.

With the language of development being inadequate to articulate the complexities and dynamics of environment, there is a need for a different way of seeing and knowing it. What kind of images are triggered and evoked in the mind when engaging in the environment? How do they form and how can they be extracted and communicated? How can they be used to 'see' the Western Ghats?

In order to enter the Ghats and the imaging of its environment, to understand the conflicts, the relationship between nature and culture, and to uncover a different imaging, it became important to begin to search for a 'local' understanding.

\subsection{Entering the Western Ghats - Malegalalli Madumagalu}

Ania Loomba (2005, p.66) suggests that literature and language "influences people as individuals," and is critical in the communication and consumption of colonial discourse. In the search for a local imaging, Kuvempu's ' novel, Malegalalli Madumagaluii offered a glimpse into feudal life in the Southwestern Ghats during the late 18oos. This is also the period when multiple colonial ideas/interventions were introduced into the local landscape including law and order, ideas of religion and technology, coffee, the boot and bicycle, post office, taxation, the Mangalore tile and the clock, just to name a few. Each of these transformed the local people and the environment.

Malegalalli Madumagalu is noted for its vivid descriptions of people, their relationships, trials and tribulations, and provincial life, and is set during the monsoon. The story is a tangled mesh of three love stories in feudal Malenadu, described in familiar categories of caste, gender, locations, species, contours, and hierarchies, as well as classifying landscapes into forest, ghat, swamp, field, tank, bund, hill, stream, river, village, temple.

One of Kuvempu's main concerns that his works were directed towards was caste inequality (Parashuramappa, 2008, Chapter 2). In Malegalalli Madumagalu, the trajectories of the protagonist, Guthi, reveal the world of the adivasi (tribal or indigenous, or 'untouchable'). 


\subsection{Extracting the Imaging - The Quasi-Local Language}

The novel, a merging of fiction and non-fiction, and written by a literary who grew up in this region, presents the inherited dominant language of the disciplines. One can read into the narrative that the author, and his imagination, is a product of post-Independence, endorsing Nehru's agenda to modernize India (Loomba, 2005, p.163).

However, in the author's reading of Malegalalli Madumagalu there are two types of imaging that are spliced together by the narrative structure, one of the text of words, its connotations and gaze; the text uses the quasi-scientific language of objects and people in space. The other is of the imaging before the text (of a way of seeing), the experience. It describes an experience in this place, one that continually changes, one that possibly comes from the author's knowing of the terrain, imaged as notational drawings. It is this intertwining or splicing of two paths (lines) of imaging, of the author's gaze and experience that constructs the quasi-local narrative.

This paper hopes to demonstrate that the imaging of the experience (notation) that has so far has been taken for granted, reveals a different structuring of the narrative, one that opens up a local way of knowing, as well as the colonial interventions that created dramatic shifts and constructed contemporary conflicts.

\section{Journey through Text ${ }^{\mathrm{iii}}$}

To engage between image and text, the research journeyed between a textual excerpt from the epic to the imaging of this excerpt (Figure 7), to demonstrate a difference and a co-existence, a 'correspondence' (Ingold, 2011). The following excerpt is from Chapter One (Puttappa, 1967), as the protagonist, Nayiguthi, is walking through the landscape:

"Though he had to pass through Lakkundha, that was not his destination. Lakkundha was just three or four miles from Simbhavi. So, he needn't have shown such anxiety if he had to go there. Even if it was dark, even if he had to wade through the thick forests of Seethur Hill, Guthi needn't really worry. He was really a tough man!

"The other thing was his attire! The reason Manja commented on his appearance was the transformation in his dress. Compared to the Marathi who was practically naked except for a short dhoti around his waist, this untouchable Guthi though dirty all over was looking good! With a red cloth tied around his head, he had a shirt on! And his dhoti reached below his knees. And the earrings! Though these earrings were nothing new, the rest of the clothing gave them a special effect! To top it all, he had shaved! And since he was fair skinned for an untouchable, he almost looked like a caste villager. He had a gunny on his shoulder to protect him from the rain and a thick black wooden staff under his arm. He was ready for the rain as well as for any fight.

"Even as Guthi started climbing the Seethur Hill it became dark and the black skies made it darker. The fireflies could be seen dancing. The drone of the cicadas was shattering his ears. Even though it was just the beginning of monsoon, since this was the thick forest and heavy rain country, these areas were full of leeches. Guthi would stop in his strides from time to time, pluck the leeches, put the same hand into his pocket to take out betel nut, betel leaves and tobacco and put them into his mouth and resume walking; and his short legs took brisk strides in the narrow path in that dense forest on the Seethur Hill. As the night became blacker, the insects' drone louder, Guthi could no more see the path, his 
legs, or the leeches that were sucking his blood. Guthi was walking by instinct. People from the town would shudder and faint at the very sight of the dark rain forests. But for Guthi, they were acquaintances and held no fears. In fact he was a part of them. Like a rock on a hillock, like a tree in the forest, he was a part of this glorious, frightful nature."

The text continually uses the language of the colonizer, an orientalist 'eye' (Said, 2003), representing caste inequalities, among landlord and immigrant worker and untouchable (Figure 4). The words highlight the 'plight' of the untouchable by positioning the protagonist as a 'native', almost 'heathen', a forest-dweller, having an array of unpredictable livelihoods. Throughout the novel, this language reinforces the nature of feudal hierarchies and inequalities, juxtaposing them with a 'better' quality of life and new systems and structures that were being deployed in the late 1800 .

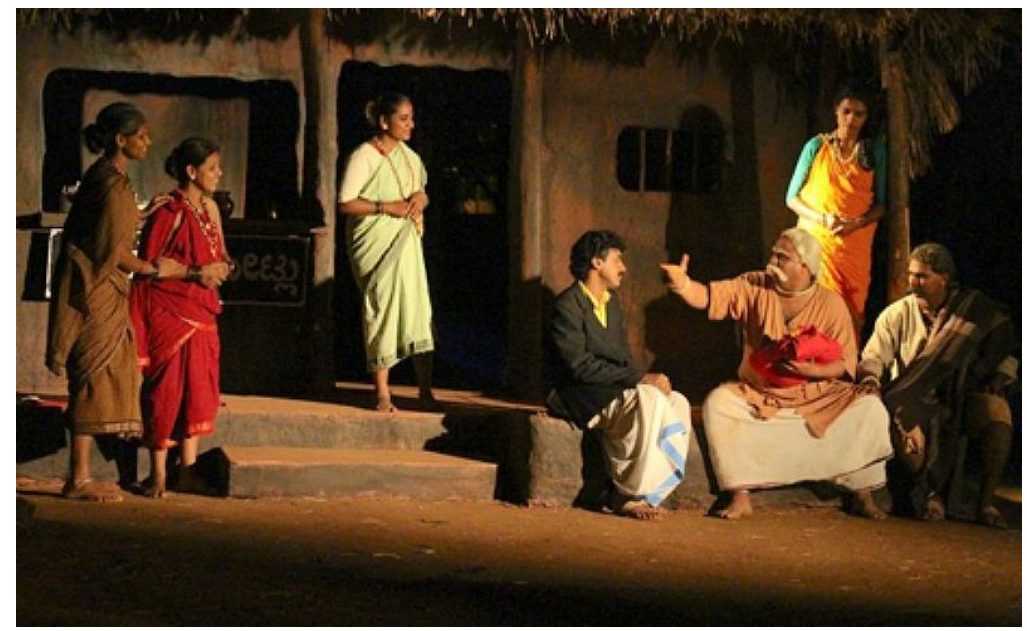

Figure 4: Photograph from the Theatre Performance, 2015. Source: https://honalu.net/2013/05/06/ / (Accessed 15 September 2018).

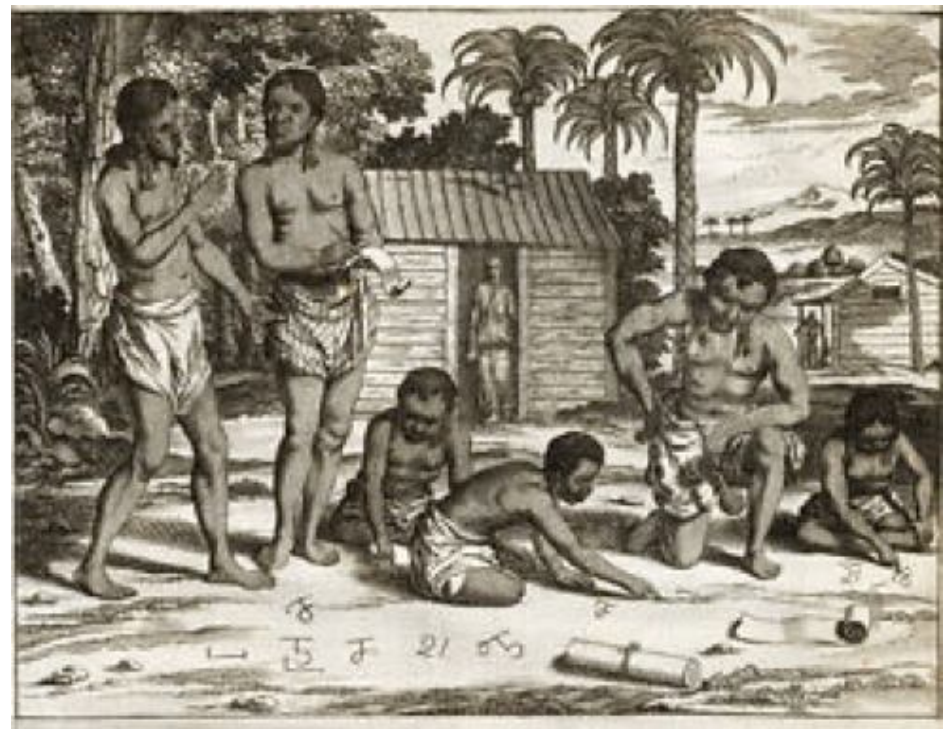

Figure 5: Sketch of a scene from Malabar, by Philippus Baldaeus (1672). Source: http://www.columbia.edu/itc/mealac/pritchett/ooroutesdata/180o_1899/education/manuscripts/manuscripts. html (Accessed 15 September 2018). 
This orientalist eye can be traced back to colonial descriptions of India and of the Malabar region. Duarte Barbosa, a Portuguese writer, who was posted in Cannanore and Cochin in the 1500s, wrote about his observations about the people and culture of the Malabar coast as 'things', entities in themselves, places and objects, painting a vivid visual, the inherited picture - as castes, appearances (Figure 5), apparel, body type, artifacts, relationships among different peoples and hierarchical structures in society (Barbosa, 1866). It is possible that Barbosa traveled with his own 'lens', that of an orientalist, perpetuating in the language of the social sciences.

It was also between the late 1700 and late 1800 s that the scientific disciplines (social, natural, physical) were being formulated and formalized, through the explorations and recordings of the Ghats (Buchanan, 1807; Cleghorn, 1861). As the Malenadu region was difficult to access due to the dense vegetation and challenging terrain of steep slopes and inundation, certain enterprises and activities arrived here later than other parts of the Ghats and southern India. The colonial enterprise of recording, surveying, mapping, categorizing and classifying and settling, were still in process, in particular to create maps, gazettes and district manuals (Sturrock: 1894), in order to manage and control the land, resources and labor (people). These procedures/practices were unknown to the local inhabitants, who lived in a different world. This world was unknown to the colonizers who deemed it incomprehensible, messy and superstitious (ibid.). The language of the disciplines, mirrored in the Western Ghats Ecology Expert Panel Report (Gadgil et al, 2011), are evident in the text of the novel: Geography, of distance, locations and spaces; Geology, of materials and artifacts; Botany, of fruits, plants, crops and species; and, Economics, of livelihood and social hierarchy.

This colonial world is one of borders, boundaries and fixed hierarchies, and in the novel is layered with the introduction of even more 'order' and systems into the landscape. With this language, the eye of the readers of Malegalalli Madumagalu is focused on caste and hierarchies, on disciplines and boundaries, while the experience of the "rain terrain" (Da Cunha, 2018) has receded into the background, a mere setting for the human drama that unfolds in the narrative (Ghosh, 2016; p. 78-79).

\subsection{Developing a Notation}

There is something else in this epic novel that has been taken for granted along with placing the monsoon in the background. Guthi, an untouchable, largely inhabits the 'outdoors' (for lack of a better word) and traverses on foot, the everyday practice of walking. The narrative is rich in its description of this ordinary practice, not just Guthi's but of every character.

This research led to drawing the walks of each character with a curiosity for what visualizing the novel in this way will offer the reader and/or the scholar. Drawing became a practice of discovery, the discovery of a new way of seeing, a new lens to see the Ghats. Kuvempu's descriptions of the characters' walks are very detailed, and so the drawings became dense with multiple textures, movements and events. The reflexive process of reading and drawing was created from following walking in the text and drawing it as a line that was continually in the making. Along with it, came its rich contextualities, materialities, spatialities and temporalities, a terrain of continual change, driven by movement (walking). 


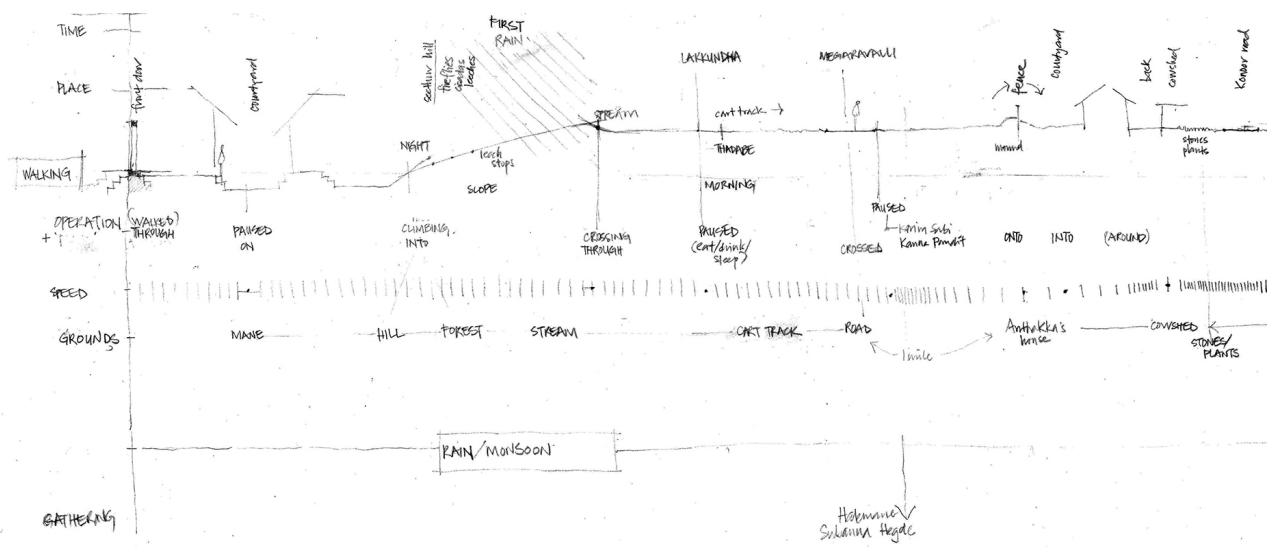

Figure 6: Partial notation of Chapter 1, Guthi's Walk in the beginning of the novel. Image created by: Deepta Sateesh.

The notation began to gather new categories (left vertical line in Figure 6) - Time, Place, Walking, Operation, Speed (or rhythm), Ground and Gathering. Walking is the line of movement over time, the line is an anchor that continually reveals inter-linkages among the categories, continually synthesizing them to construct place.

This notation differs from the words of the text, offering a different narrative structure that reveals the relationalities between the foot and the ground, the contextual and textural world, and the nature of how one moves across the terrain. The new construction restructures what we read of the story and landscape, offering the possibilities of seeing it critically and creatively.

The critical reading of the text reveals a number of concepts and fields of study that are valid as "materializations of history" but have never been elevated (Williams, 1989), and instead taken for granted. These events reveal issues and conflicts, in the interdisciplinary field of political ecology in particular, that arise from the hegemonic language and its imaging of objects and space.

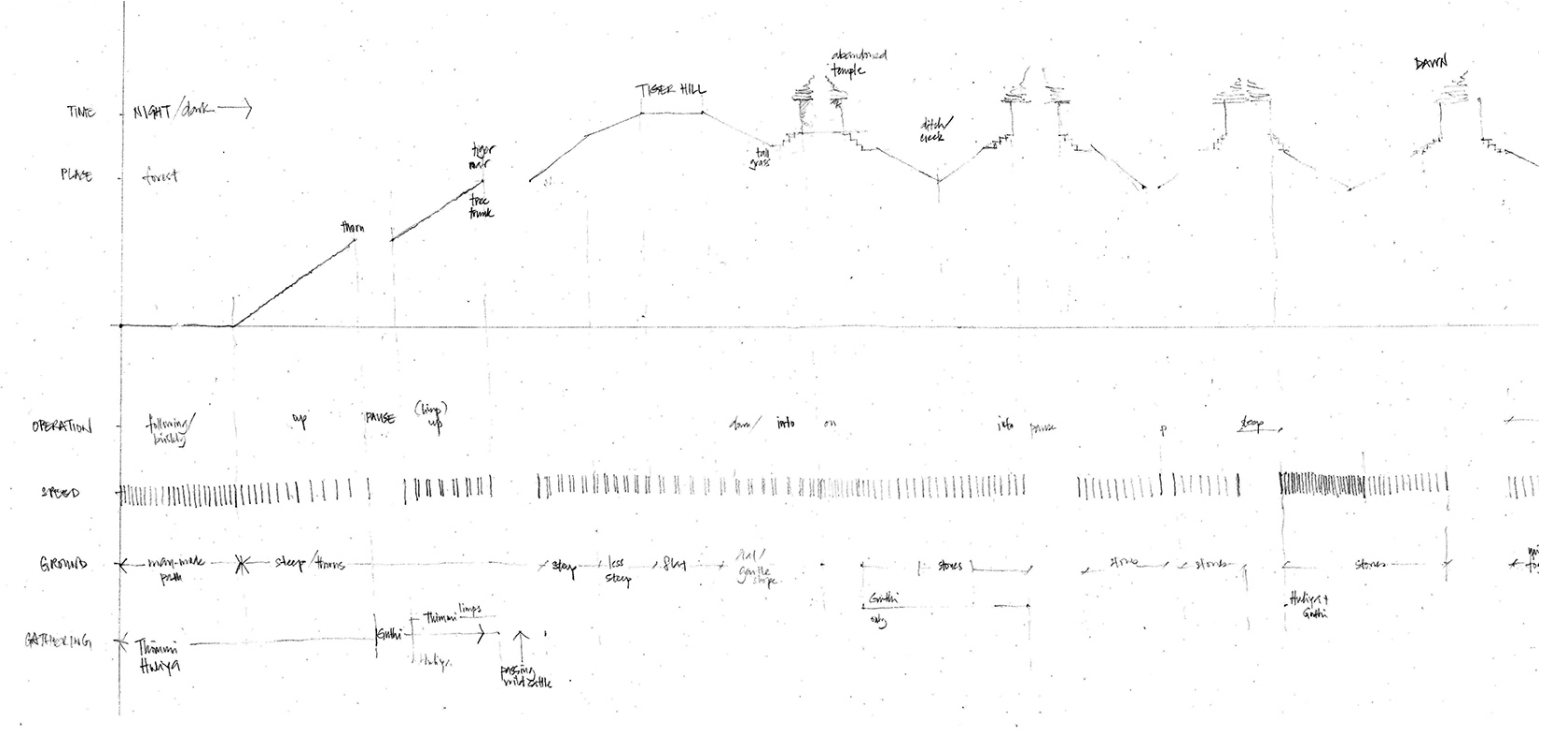

Figure 7: Partial notation of Chapter 23, Nayiguthi and Thimmi's walks. Image created by Deepta Sateesh. 
The notation simultaneously reveals a new imagination, of possibilities of meshworks (Ingold, 2011), events and a way of knowing by walking. The eye moves along the lines, across lines and categories, and a certain rhythm of time is revealed. It leads one through the landscape of experience and events. These gatherings or events hold trajectories of lines of movement. The lines of walking continually move forward gathering and generating events; the lines are of walking across time (Figure 7). And time is seen in the quality of the atmosphere, rain, sun, clouds, dark, light, rather than a clock.

\subsection{A Revealing Event}

In the novel, one of the most significant 'events' in terms of colonial interventions is the bicycle incident in Betadahalli near the hakkal land. In the words of the text, it is a time of humour, of juxtaposing the European with the native, technology with tradition, the individual with the collective. It is the missionary priest who introduces the bicycle to one of the lower caste members, Doddabeera, in the hope of luring the heathen into converting to Christianity (Figure 8). With many other local spectators, the priest had them all enraptured with this new instrument of movement. Unfortunately for the brave Doddabeera, who even had support holding the bicycle, he lost his balance and fell into a ditch. It is described that he lost balance due to the wheels trying to traverse the rocky pebbly ground, making it a bumpy ride.

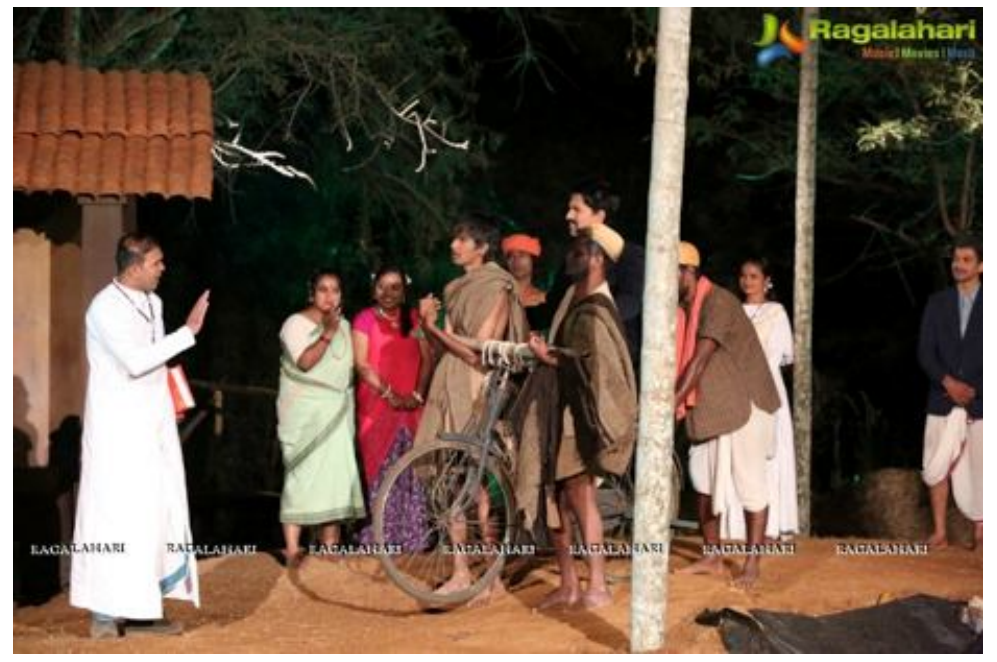

Figure 8: Photograph from the Theater Performance, 2015. Source:

http://www.ragalahari.com/localevents/184659/malegalalli-madumagalu-theatre-play-photos/image104.aspx (Accessed 15 September 2018). 


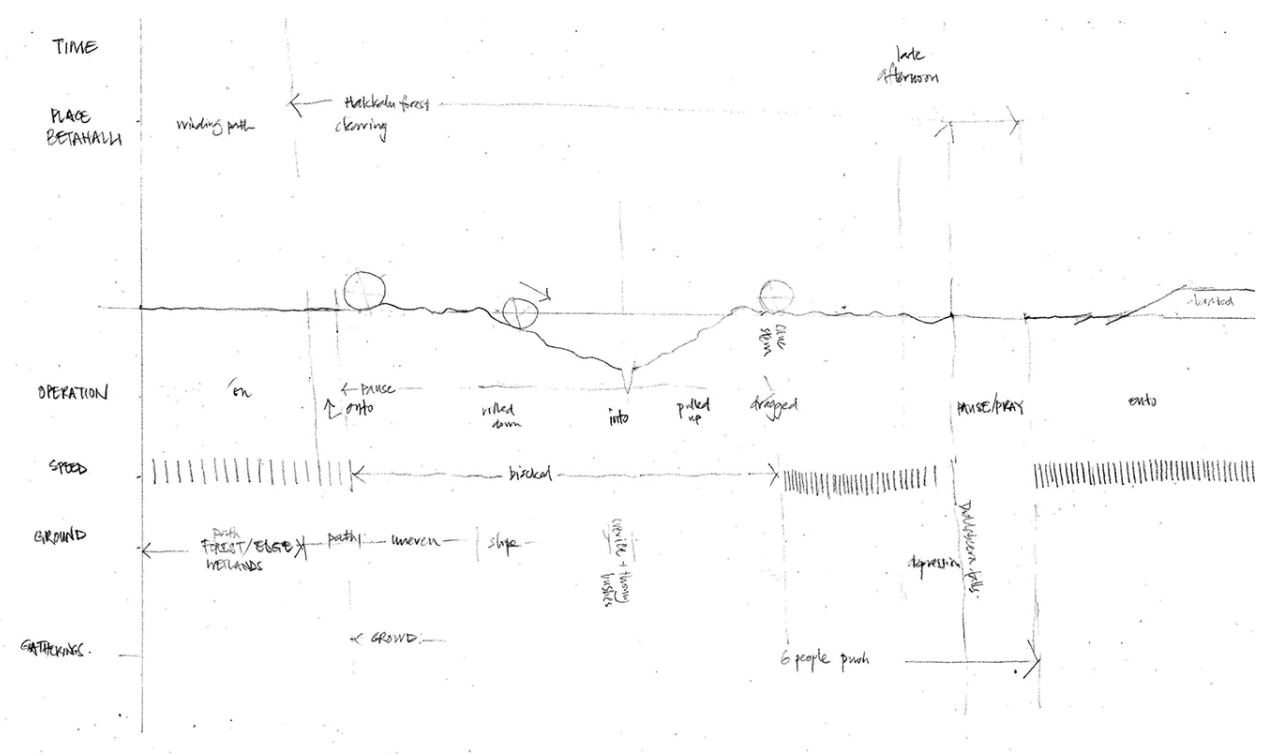

Figure 9: Partial notation of Chapter 18, the bicycle ("bisekal") event. Image created by Deepta Sateesh.

While in the reading of the text this is an amusing event, the notation demonstrates a shift as the line quality changes from a line of walking that is 'even' in nature to a wavy or bumpy line (Figure 9). Up until this moment, walking was a smooth experience, which is a relational practice (or practice of correspondence) between the foot and the ground (Ingold, 2011). However, the experience is no longer smooth and instead is seen as 'bumpy', forcing one to look at the ground as a surface of contours. This is a moment of technology, of introducing the wheel to replace the foot, delinking the foot from the ground, disabling knowing by walking. It is the moment that the idea of an uneven surface is introduced through the bicycle. This seemingly chance event, planned by the priest, opens up issues of colonization, slowly shifting from ways of knowing the terrain through foot to distancing oneself from it, instead, by knowing the wheel in order to move.

The significance of alienating the foot from the ground is immense, as it creates a need for flatness, a need for a reliable continually even surface for the wheel to move along. It creates a problem for which the solution is flatness. With this problem, comes a whole set of solutions developmental projects that have to do with smoothening or flattening land, of constructing a surface and maintaining this flat condition, including roads, buildings, factories, and so on.

Smethurst suggests that this increase in aspiration and the increased demand in the colonies, subsequently raised bicycle sales in England (2015). The introduction of the bicycle was simultaneously a global event across all British colonies (ibid.; p. 125-129), exposing social structures and hierarchies, nurturing aspirations towards 'western' culture and its associated technology. Simultaneously, it initiates the notion of an even ground, requiring the land to be flattened for the wheel to traverse. This notion led to road building as a way for the colonizers to connect their centers of extraction and trade; this, over time, led to massive infrastructural projects. The British began to build India's extensive road network seeing that the land was too uneven for wheeled vehicles as the demands grew. Today these large-scale infrastructural changes continue on a massive scale - expressways, flyovers, cross-country tollways; they physically divide communities, ecologies, and dominate the landscape (Mann, 2015; p. 347), connect regions and cities, raw materials to ports, and international trade (Studer, 2015; p. 55-59) expanding and displacing human-ground relationships on many levels: from foot to wheel (uneven to even), from 
manual to mechanical (rhythm and the clock), from mud to metaled road (porous to impervious). This is a conflict arising from dependency on a surface (bicycle - road), rather than a generative interdependency (adaptive foot - shifting ground) - a conflict between local and global.

The separation of the foot from the ground (Ingold, 2011; p. 35) may be seen as strategic, in order to make room for colonial interventions that were coming up against resistance movements across the Ghats from the early to late 180os (Bhat, 1998). Simultaneously, this separation displaces the local inhabitants from their world, enslaving them to that of the European world, the colonial eye.

Another significant issue this particular event reveals is the idea of hakkal. This rugged terrain is described in words as a forest with stunted trees and thin vegetation amidst a dense rainforest. Its ruggedness is deemed inadequate by the bicycle. However, in colonial texts, hakkal is described as dry grassland "irrigated by rain and used for raising vegetables" (Buchy, 1995) and "upland area that has never been leveled for rice cultivation" (Sturrock, 1894). Hakkal lands were later taken over by the Forest Department under the 'reserve forest category' (Shrinidhi \& Lele, 2001). It is a term for what is now a particular grassland terrain, however another meaning is possible - a terrain that is multiple (in practices) and dependent on and anchored by rain.

Unfortunately, in many colonial records, these grasslands were seen as unproductive wastelands that then were re-categorized as revenue land, land to be developed and built on, to make productive by flattening it. This way of seeing hakkal gives no value to its local transitional activities and spatio-temporal appropriations (grazing, nesting, digging, gathering, crossing), but sees it with permanent borders and boundaries. Conservation scientists and activists retort with claims of the grassland's ecological value, supporting a rich biodiversity (Robin and Nandini, 2012), and continue to demarcate it within permanent boundaries to protect the space from development. Both sides of the conflict reflect the outsider's inability to come to terms with the dynamic nature of this terrain and its relation to its context within the monsoon and Ghats.

It is evident that this new visualization (notation) of the novel exposes an idea that changes the local inhabitant bringing them onto the ground of the colonizer, that of settlement. The imaging reveals a fundamental misunderstanding of our past. It is not that the local people are backward and "heathen", as the Basel Missionaries wrote about them (such as A. C. Burnell, 1894). They possibly saw different things, knowing their world through their feet, connecting deeply with the elements and natural processes. The two ways of seeing are different: the first (gaze) is of a world of objects in spaces, and the latter (notation) of a world of practices across time.

Unlike the words in the text of Malegalalli Madumagalu, the notation draws attention to the nature of the ground and its relationship with the foot. The notation reveals the transformations of the landscape and their relationalities. The notation offers a new way of 'seeing' - through the lens of walking. The line of walking constructs a new understanding of movement across a shifting terrain. The line privileges time and rain, allowing the reader to see the emergent events (Deleuze \& Guattari, 2005) that are a knotting (Ingold, 2011) of trajectories that are held for a moment and released, a threshold (no longer a boundary, but a condition of liminality, in-between, in the making, kaccha). 


\section{Visual Literacy - Nature-Culture Divide}

Today, there is a great reliance on visuality to make sense of the world, to know the world. Text and image give one a certain reading of the Ghats, and it is the conditioned or taught eye that cannot see the Ghats beyond this reading - the eye sees only the representation of an idea or notion, that is a product of the various forces (political, economic, social) of the times in the place. One depends on and takes for granted the image that is so ingrained in one's mind, in laws, text books, language and culture. One does not question where the image came from or how it came to be, taking it for granted as true. Seeing in this way means to be able to see clearly, to see through clear air, the 'things' in the world; to see without rain that blurs one's sight. "Rains blurred the line between land and water that they wanted to see with clarity. As such, they [East India Company] waited out the monsoon, preferring to map a fair weather landscape wherein the monsoon is a visitor rather than resident" (Mathur \& Da Cunha, 2010). This seeing with "dry eyes" is a lens that is not local; a lens formed by a different experience and understanding of place - a colonial lens that has shaped the way we engage with (not in) and design for the Western Ghats. There is a need for a new lens and imaging that comes from the ground of the Ghats - not of the forest, escarpment, coast or resource, but of a way of life in wetness and living that is unseen and unarticulated, and much more complex and ordinary.

The quasi-scientific language calls attention to the object or individual thing qualified by its own/intrinsic characteristics, and brings them into the disciplines of geography, geology, botany and economy, all demarcated by lines and boundaries. The images call attention to how the Ghats have been spatialized. And it is this imaging of the places and the language that is used to describe them that has given rise to conflicts on the ground.

This language of the description of the Western Ghats has led to many scientific, sociopolitical, legal and economic activities, led by expert groups from various disciplines, that perpetuate these identities, inventing corroborating information of these identities. But, with its recent UNESCO designation the Western Ghats has become an extremely contested terrain, with rising conflicts between environment and development, resident and government, livelihoods and market. These conflicts may be attributed to the way in which we see the region that is described by this inherited language - of visual literacy and socio-political literacy. In this construction, or act of design, there is actually no clash as they are two worlds that meet on the terms of the colonizer - a valorization of the colonial language/construction. The conflicts/problems are articulated as two sides of a divide manifested through inherited language - of development/environment, global/local, conservation/evolution, and nomad/settler. And these conflicts are framed as wicked problems that there is the possibility of negotiations (that the two sides can meet) or solutions.

This inherited literacy gives rise to the individual, rights, property, place of rich biodiversity but can challenge the notion of species, cities, forests, gender, resources, conservation/inviolate spaces, quantifying them rather than qualifying their relational aspects. The challenge is to break through entrenched knowledge of various things - of geography, social system, coming from colonial, accepting a system of the world that may not exist - can be seen through the dissonances in culture, practices. This notion begins to draw boundaries and separates and groups things creating an object-ness rather than seeing the relational aspects homologous rather than analogous, that then begins to create boundaries. 


\section{Conclusion: the Line of New Possibilities}

To plan conservation and development, the most fundamental practice is that of drawing lines, to create maps, sections and views, each drawing unable to capture reality by itself. These lines are used to define space, whether of a room or piece of furniture, a building or land use. In this context, the line defines space, divides surface and differentiates inside from outside (Ching, 2007). Drawing itself denotes an articulation and boundaries, as an idea. The lines may change in scale but they all act as enclosures (Edney, 1999; Ingold, 2015). Here, the line as a spatial element freezes time, excludes time.

However, the line in the notation is drawn differently, as an open plot that continually gathers events and generates temporality. Here is a possibility of it being inclusive of space, but temporal space, or space temporally. The line that does not enclose (if opened up, infinitely) does something else - in the notation, the line is of walking, of movement, of time. Movement is time and vice versa. It can thicken with new elements of context, materials and gatherings, becoming diverse and particular to the moment, rather than imposing a universal prior image and plan.

The new categories from the notation, of Time, Place, Operation, Speed, Ground and Gathering, allow one to construct the complexity of places by walking the terrain, through experience. They privilege wetness, depth, horizon, events, rain and ordinary everyday practices over space, surface and settlement. They offer new things to record in the field, when investigating a conflict or an event, rather than the disciplinary categories. Each of the categories can be recorded in creative ways, through multiple media of drawing, sketching, photographing, tracing and moving images. The synthesis of these media can enable one to work with a transforming terrain and all that corresponds with it.

The line of walking is experienced as an ordinary everyday practice, one that is normal, universal; it is a datum for engaging in the terrain. The line itself is a threshold, and no longer divides [nature from culture] but is one that is generative. The line gathers as it moves, holding and releasing; here "culture is enclosed in nature, nature is reworked in culture, so that we cannot tell the difference" (Dharwadkar, 2004). The line holds a nature-culture continuum.

\section{Notes}

${ }^{i i}$ Kuppali Venkanna Gowda Puttappa (Kuvempu), a renowned literary figure and scholar, grew up in the Malenadu region, Western Ghats.

iii Malegalalli Madumagalu is one of Kuvempu's two epic novels both situated in the Malenadu region of Karnataka, both set in the late 18oos. Malegalalli Madumagalu, meaning "Bride of the Hills", is situated in a moment shortly after scientific forestry was introduced in the Ghats, the first Forest Act passed, and British colonizers were completing their survey and settlement of the Southwestern Ghats.

iv This is an extract from an unpublished English translation of Malegalalli Madumagalu by Dr. Srinivasa Gowda.

\section{References}

Assadi, M. (2004). Forest Encroachments, Left Adventurism and Hindutva. Economic \& Political Weekly, 39(9), 882-885.

Barbosa, D. (1866). A Description of the Coast of East Africa and the Malabar. London: Hakluyt Society. 
Bawa, K., Das, A., Krishnaswamy, J., Karanth, U., Kumar, S., \& Rao, M. (2007). Western Ghats E Sri Lanka Biodiversity Hotspot. Critical Ecosystem Partnership Fund (CEPF).

https://www.cepf.net/sites/default/files/western-ghats-ecosystem-profile-english.pdf

Berger, J. (2008). Ways of Seeing. British Broadcasting Company and Penguin Classics.

Bhat, S. (1998). South Kanara, 1799-1860: A Study in Colonial Adminstration and Regional Response. New Delhi: Mittal Publications.

Buchanan, F. (1807). A Journey from Madras through the countries of Mysore, Canara and Malabar. London: Fort. Cadell and W. Davies.

Buchy, M. (1995). The British Colonial Forest Policy in South India, a Maladapted Policy? Les Sciences Hors d'Occident Au XXe Siecle, 3 (Nature et Environnement), pp. 33-58.

Burnell, A. C. (1894). The Devil Worship of the Tuluvas. Bombay: Education Society's Skam Press.

Castree, N. (2014). Making Sense of Nature - Representation, Politics and Democracy. Oxon: Routledge.

Ching, F. D. K. (2007). Architecture: Form, Space and Order. Hoboken, New Jersey: John Wiley \& Sons, Inc.

Cleghorn, H. (1861). The Forests and Gardens of South India. London: W. H. Allen \& Co.

Cons, J. (2017). Seepage. Cultural Anthropology.

Cunha, D. da (2018)."River Literacy and the Challenge of a Rain Terrain" in Critical Humanities from India: Contexts, Issues, Futures, edited by D. Venkat Rao. Routledge India.

Deleuze, G., \& Guattari, F. (2005). A Thousand Plateaus (Eleventh P). Minneapolis: University of Minnesota Press.

Dharwadkar, V. (Ed.) (2004). Collected Essays of A.K. Ramanujan. Oxford University Press.

Edney, M. (1999). The Ideologies and Practices of Mapping and Imperialism. In Mapping an Empire: The Geographical Construction of British India, 1765-1843. Chicago: The University of Chicago Press.

Forbes, J. (1813). Oriental Memoirs: Selected and Abridged from a Series of Familiar Letters written during Seventeen Years Residence in India; including Observations on Parts of Africa and South America, and a Narrative of Occurrences in Four Indian Voyages. Volume I. London: White, Cochrane and Co. Horace's Head.

Gadgil, M., Krishnan, B. J., Ganeshaiah, K. N., Vijayan, V. S., Borges, R., Sukumar, R., ... Subrahmanyam, G. V. (2011). Report of the Western Ghats Ecology Expert Panel. The Ministry of Environment and Forests, Government of India.

Ghosh, A. (2016). The Great Derangement. Gurgaon: Penguin Books India.

Heidegger, M. (1996). Being and Time. Albany: State University of New York Press.

Ingold, T. (2015). The Life of Lines. London and New York: Routledge.

Ingold, T. (2011). Being Alive: Essays on Movement, Knowledge and Description. London and New York: Routledge.

Loomba, A. (2005). Colonialism/Postcolonialism (2nd ed.). Oxon: Routledge.

Mann, M. (2015). South Asia's Modern History: Thematic Perspectives. Oxon: Routledge.

Mathur, A. \& Da Cunha, D. (2010). Visualizing India's Terrain. India in Transition. Acessed from https://casi.sas.upenn.edu/iit/mathurdacunha.

Parashuramappa, S.R. (2008). Feudal Relation in Rural Karnataka. Chapter 2: Feudal Relations in Malenadu: K. V. Puttappa's Novels. Mysore: University of Mysore. Accessed from http://shodhganga.inflibnet.ac.in/handle/10603/39852.

Puttappa, K. V. (1967). Malegalalli Madumagalu. Bangalore: Udayaravi Prakashana.

Puttappa, K. V. (n.d.). Malegalalli Madumagalu. (Dr. S. Gowda, Trans., unpublished). Bangalore: Udayaravi Prakashana. (Original Work published in 1967)

C. Basavalingaiah (Director). (2015, March 18). Malegalalli Madumagalu by Kuvempu, Kalagrama, National School of Drama, Jnanabharathi, Bangalore University.

Robin, V. V., \& Nandini, R. (2012). Shola habitats on sky islands - Status of research: On montane forests and grasslands in southern India. Current Science, 103(12), pp. 1427-1437.

Said, E. W. (2003). Orientalism. London: Penguin Books.

Shrinidhi, A. S., \& Lele, S. (2001). Forest Tenure Regimes in the Karnataka Western Ghats: A Compendium (No. 90). Bangalore. 
Smethurst, P. (2015). The Bicycle - Towards a Global History. London: Palgrave Macmillan. doi:10.1057/9781137499516.

Steinberg, P., \& Peters, K. (2015). "Wet Ontologies, Fluid Spaces: Giving Depth to Volume through Oceanic Thinking" in Environment and Planning D: Society and Space, 33(2), pp. 247-264. http://doi.org/10.1068/d14148p.

Studer, R. (2015). The Great Divergence Reconsidered. Cambridge: Cambridge University Press. pp. 55-59. Sturrock, J. (1894). Madras District Manuals: South Canara, Volume I. Madras: Superintendent, Government Press.

Williams, R. (1989). Culture is Ordinary [1958]. In Resources of Hope: Culture, Democracy, Socialism. London: Verso. pp. 91-100.

Deepta Sateesh is a design leader in development alternatives and conservation futures. She conceptualizes and facilitates complex projects concerned with the environment and communities, to catalyze socio-ecological change in regional ecosystems and landscapes in conflict. For her, design is a creative process of inventing, adapting and imagining ways of seeing, engaging and acting in open dynamic systems. Her practice and research lie at the intersection of design and environment, climate change adaptation, movement and migration, and policy planning and design, in the areas of resilience and sustainable development. Deepta holds a Master of City Planning from the School of Design (previously Graduate School of Fine Arts), University of Pennsylvania (2000), and a Bachelor of Architecture from Manipal Institute of Technology (1998). 